\title{
Research on the Development Path of Campus Football in Zhejiang Province
}

\author{
Chongjiang Zhan ${ }^{1}$, Boliang $\mathrm{Xu}^{2}$, Li Cao ${ }^{3}$ \\ ${ }^{1}$ Jiyang College of Zhejiang A\&F University, Shaoxing, Zhejiang, China \\ ${ }^{2}$ Zhejiang Zhuji Second High School, Zhuji, Zhejiang, China \\ ${ }^{3}$ Zhejiang Yuexiu University, Shaoxing, Zhejiang, China
}

\begin{abstract}
Through combing the domestic and foreign literature on campus football and using questionnaire surveys, interviews and other methods, a comprehensive analysis of the development path of campus football in Zhejiang Province is conducted. Research conclusions: Regarding the popularization status, Zhejiang campus football penetration rate is regional. High penetration rate is mainly concentrated in eastern Zhejiang, southern Zhejiang, northern Zhejiang and Zhejiang middle-developed cities, and the underdeveloped regions of western Zhejiang need to be strengthened. Regarding the curriculum setting, there is no uniform standard for curriculum setting, and the teaching hours, syllabus, teaching content and teaching evaluation of each school are also different. Regarding the psychological willingness, parents and schools in junior and senior high schools do not support football, but students are more interested in football. And regarding the competition system, there are differences in the campus football competition system between primary and secondary schools and colleges.
\end{abstract}

Key words: campus football; curriculum setting; psychological willingness; competition system

\section{Introduction}

In June 2009, the State Sports General Administration and the Ministry of Education jointly launched the national youth campus football promotion activities, aiming to carry out football activities in universities, primary and secondary schools nationwide. Since then, China's youth football has entered a brand-new development stage. And the research on the development and popularization of campus football in China has become the focus of researchers' attention. In March 2015, the General Office of the State Council issued the "Overall Plan for the Reform and Development of Chinese Football" (hereinafter referred to as the "Plan"), which laid the tone for the development of football at the national level for the first time. It pointed out the way forward for the development of campus football in China, which policy and strength are unprecedented.

After the development and practice of the new campus football in two five-year plans, what is the popularity and current situation of campus football in Zhejiang Province? How about the curriculum setting of campus football? What are the willingness of family, school and students for football? How is the campus football competition system? These problems are closely related to campus football. Therefore, studying them is conducive to further promoting the development and popularization of campus football, accumulating valuable experience for promoting campus football 
nationwide, cultivating football reserve talents and enhancing students' physical health.

\section{Research Objects and Methods}

\subsection{Research object}

This article takes the current situation of campus football development in universities, primary and middle schools in Zhejiang Province as the research object.

\subsection{Research methods}

\subsubsection{Literature data method}

Based on the research purpose and content needs of this subject, this paper provides theoretical support for the research through extensive collection and collation of literature related to the research. And you can also visit the websites of the State Sports General Administration, the Ministry of Education, and the Education Department of Zhejiang Province through the internet and check all kinds of information about "campus football" activities.

\subsubsection{Expert interview method}

On the basis of theoretical research, face-to-face interviews, telephone interviews and WeChat, we visited experts and scholars in pedagogy, school physical education and football, and managers of campus football activities to listen to their views, suggestions and opinions on the development of campus football activities.

\subsubsection{Questionnaire survey method}

Distributed in forms of submission, email and WeChat, the following four questionnaires were developed: Questionnaire on the Popularization of Campus Football in Zhejiang Province, Questionnaire on the Curriculum Setting of Campus Football in Zhejiang Province, Questionnaire on the Psychological Willingness of Family, School and Students to Campus Football and Questionnaire on the Development of Campus Football Competition in Zhejiang Province.

\subsubsection{Logical analysis method}

By inductive and deductive methods, this paper analyzes, synthesizes, promotes and generalizes the unbalanced popularization of campus football, the single curriculum setting, the different psychological willingness of family, school and students, and the similarities and differences of competition system, and then refines the core concepts, forms judgments, and makes logical reasoning on the factors affecting campus football.

\subsubsection{Mathematical statistics method}

The collected valid questionnaires were screened and sorted out. SPSS20.0 software was used to analyze and process the data, and the research data was visualized in the form of charts.

\section{Results and Analysis}

This paper investigates the situation of campus football activities in some schools in Zhejiang Province, reveals the existing problems and puts forward suggestions for improvement, so as to facilitate the in-depth promotion and healthy development of the burgeoning campus football activities in Zhejiang Province.

\subsection{Current situation of campus football popularization in Zhejiang Province}

Popularization is the basic requirement of campus football. Each school offers football lessons for all students every week, and organizes after-school football training and intramural football matches. It aims to implement popularization, so that the number of campus football participants will increase from less to more, and the situation will gradually improve. So, what is the popularization of campus football in Zhejiang Province? What is the connection between penetration rate and regional differences? Before the analysis, we first define a concept, a football class once a week for 45 minute with football characteristics (According to the national selection standard of campus football characteristic schools). See Table 1 for details. 
Table 1. Questionnaire on the current situation of campus football popularization in Zhejiang Province $(\mathrm{N}=220)$

\begin{tabular}{c|c|c|c|c}
\hline Region & City & Number of schools & Characteristic schools & Frequency \\
\hline \multirow{2}{*}{ Eastern } & Zhoushan & 14 & 10 & $71.4 \%$ \\
\cline { 2 - 5 } Zhejiang & Ningbo & 26 & 23 & $88.5 \%$ \\
\cline { 2 - 5 } & Taizhou & 18 & 15 & $83.3 \%$ \\
\hline \multirow{2}{*}{ Northern } & Jiaxing & 17 & 14 & $82.3 \%$ \\
\cline { 2 - 5 } Zhejiang & Huzhou & 18 & 15 & $83.3 \%$ \\
\hline \multirow{2}{*}{$\begin{array}{c}\text { Central } \\
\text { Zhejiang }\end{array}$} & Jinhua & 22 & 20 & $90.9 \%$ \\
\cline { 2 - 5 } & Hangzhou & 28 & 26 & $78.9 \%$ \\
\cline { 2 - 5 } & Shaoxing & 19 & 15 & $44.4 \%$ \\
\hline \multirow{2}{*}{$\begin{array}{c}\text { Western } \\
\text { Zhejiang }\end{array}$} & Quzhou & 18 & 8 & $86.7 \%$ \\
\cline { 2 - 5 } Southern & Lishui & 15 & 7 & \\
Zhejiang & Wenzhou & 25 & 22 & \\
\hline
\end{tabular}

Table 1 shows that Ningbo, Jinhua, Hangzhou and Wenzhou are the prefecture-level cities with high penetration rate of campus football, accounting for $88.5 \%, 90.9 \%, 92.8 \%$ and $88 \%$ respectively, while Lishui and Quzhou are the lowfrequency cities, accounting for $46.7 \%$ and $44.4 \%$ respectively. There is a clear gap with Ningbo, Jinhua and Hangzhou, indicating that the penetration rate is insufficient and needs to be strengthened. It also shows that the overall development of campus football in Zhejiang Province is unbalanced and polarized, and the penetration rate in eastern, central and southern Zhejiang is significantly higher than that in western Zhejiang. By analyzing the reasons, it is found that Hangzhou, Ningbo, Jinhua and Wenzhou are the four economic pillars of Zhejiang Province, with strong economic capacity and sufficient financial support. While funding is not only an important guarantee for carrying out campus football activities, but also a key factor affecting the popularization of campus football. Therefore, due to geographical reasons, the relatively backward economy of western Zhejiang has formed a great resistance to the development of campus football.

3.2 The setting of campus football curriculum in Zhejiang Province

The development of campus football curriculum should follow the principles of integrity, education, human-oriented and interest. Besides, it should draw up a two-stage curriculum outline consisting of curriculum outline concept, teaching guideline and competition guideline, which need to embody the principles of compiling teaching materials which are interesting, practical and expansive, and adopt the way of organizing curriculum content by transforming curriculum content into teaching materials and teaching. This paper puts forward the curriculum development strategy of combining the spirit development curriculum based on the curriculum standard with other subject knowledge and off-campus sports activities, and paying attention to the training of curriculum developers and implementers. And it is an important task in the development of school-based football curriculum in universities, middle schools and primary schools to formulate the curriculum outline according to students' physical and mental characteristics, set teaching objectives, stipulate teaching contents and provide guiding suggestions. Development of football teaching syllabus in schools at all levels in Zhejiang Province can be seen in Table 2.

As shown in Table 2, the primary school football focuses on cultivating interest. It allows children to touch the ball, interact and assist more, and experience the happiness of success. In junior high school, let children exercise and hold the ball, create movements and cultivate children's autonomy, and encourage children to judge through their own understanding and pay attention to individual differences. Train students' physical qualities such as "walking, running, jumping and throwing" and basic skills such as "shooting and passing" in the form of games. And let children interact and assist more, so as to experience the happiness of success. In senior high school, students' technical and tactical practice is strengthened, and the transformation from single technical action to multiple technical actions and from single tactics to 
multiple tactics is realized. At the university stage, it focuses on cultivating students' ability of creation and application. With the guarantee of technology and physical quality, children should improve their tactical application ability, give play to their creative football thinking and cultivate team spirit.

Table 2. The situation of the establishment of school football syllabus in Zhejiang Province

\begin{tabular}{|c|c|c|}
\hline Stage & The goal of outline & Teaching guidance outline \\
\hline Primary school & $\begin{array}{l}\text { 1. Cultivate interest; } \\
\text { 2. Familiar with sphericity. }\end{array}$ & $\begin{array}{l}\text { 1. Happy football; } \\
\text { 2. Practice ball sense; } \\
\text { 3. Unite and help each other; } \\
\text { 4. Teach students in accordance } \\
\text { with their aptitude. }\end{array}$ \\
\hline Junior high school & $\begin{array}{l}\text { 1. Training of football } \\
\text { knowledge and skills; } \\
\text { 2. Training of football culture. }\end{array}$ & $\begin{array}{l}\text { 1. Exercise holding the ball and } \\
\text { creating movements; } \\
\text { 2. Cultivate children's } \\
\text { autonomy; } \\
\text { 3. Cultivate children's } \\
\text { independent thinking ability; } \\
\text { 4. Cultivate students' aerobic } \\
\text { and anaerobic endurance; } \\
\text { 5. Cultivate the basic skills of } \\
\text { "shooting and passing". }\end{array}$ \\
\hline Senior high school & $\begin{array}{l}\text { 1. Strengthen technical practice; } \\
\text { 2. Strengthen tactical learning. }\end{array}$ & $\begin{array}{l}\text { 1. Transformation from single } \\
\text { technical action to multiple } \\
\text { technical actions; } \\
\text { 2. Transformation from single } \\
\text { tactics to multiple tactics. }\end{array}$ \\
\hline University & $\begin{array}{l}\text { 1. Strengthen the integration of } \\
\text { technology and tactics; } \\
\text { 2. Strengthen the ability to use } \\
\text { techniques and tactics. }\end{array}$ & $\begin{array}{l}\text { 1. Improve the tactical } \\
\text { application ability; } \\
\text { 2. Give full play to creative } \\
\text { football thinking and cultivate } \\
\text { team spirit. }\end{array}$ \\
\hline
\end{tabular}

The contents of campus football courses can be divided into basic football knowledge, common physical training, football skills, football tactics and football rules, as shown in Table 3. It can be seen that the contents of campus football courses at the four levels of primary school, junior high school, senior high school and university are arranged as follows, including ball sense, theory, technology, tactics and physical quality requirements. Among them, primary schools do not have high requirements for tactics. The theoretical cognition level is gradually improved, the technique is from easy to difficult and the tactics are from simple to complex, and the physical exercise load is from small to large. The reasons are mainly related to the age structure of students and the law of physical and mental development. Universities and primary schools have 2 class hours a week and 32 class hours per semester. Primary schools have extra-curricular physical exercises and extra-curricular sports activities, while universities have extra-curricular physical exercises. However, junior high schools and senior high schools have only 1 class hour per week, each with 16 class hours. Moreover, there are no extra-curricular physical exercise and big inter-class activities, if any, it is just a form. The reason for this result is that the study pressure in primary schools and universities is less than that in junior high schools and senior high schools. While junior high schools and senior high schools face the pressure of entering the higher school, and the single pursuit of the rate of entering higher school by schools and parents has greatly reduced the time for students to deal with football.

The evaluation standard of sports skills of campus football students is based on the characteristics of teenagers' physical and mental development and the rules of football training, and the main goal is to build a national evaluation system of youth's campus football skills. Using the method of constructing scientific evaluation model, we can make normative and quantitative evaluation on the quality and effect of students' football course learning, which has a positive guiding role in promoting the construction of evaluation mechanism of campus football and improving the quality of 
teaching in football class and after-school training. It is found that there is no uniform standard for the evaluation methods of campus football in universities, senior high schools, junior high schools and primary schools in Zhejiang Province.

Table 3. The content and class hours arrangement of campus football course in Zhejiang Province

\begin{tabular}{|c|c|c|}
\hline Stage & Course content & Class hours/ semesters \\
\hline Primary school & $\begin{array}{l}\text { 1. Sense of ball: shaking up the } \\
\text { ball, stepping on the ball and } \\
\text { pulling the ball; } \\
\text { 2. Theory: Understanding of } \\
\text { Ball and soccer field; } \\
\text { 3. Techniques: dribbling, } \\
\text { passing and catching; } \\
\text { 4. Body: coordination, agility } \\
\text { and endurance. }\end{array}$ & 32 \\
\hline Junior high school & $\begin{array}{l}\text { 1. Sense of ball: shaking up the } \\
\text { ball, pulling the ball and } \\
\text { crossing the ball; } \\
\text { 2. Theory: the history and rules } \\
\text { of football development; } \\
\text { 3. Techniques: dribbling, } \\
\text { passing and catching; } \\
\text { 4. Tactics: one person or two } \\
\text { people; } \\
\text { 5. Body: coordination, agility, } \\
\text { strength and endurance. }\end{array}$ & 16 \\
\hline Senior high school & $\begin{array}{l}\text { 1. Sense of ball: tipping, } \\
\text { pushing, dialing, pulling and } \\
\text { buckling; } \\
\text { 2. Theory: Rules; } \\
\text { 3. Techniques: dribbling, } \\
\text { passing and catching; } \\
\text { 4. Tactics: small; } \\
\text { 5. Body: strength and } \\
\text { endurance. }\end{array}$ & 16 \\
\hline University & $\begin{array}{l}\text { 5. Sense of ball: tipping, } \\
\text { pushing, dialing, pulling, } \\
\text { buckling and picking; } \\
\text { 6. Theory: application of rules; } \\
\text { 7. Technology: the application } \\
\text { of technology; } \\
\text { 8. Tactics: local and overall; } \\
\text { 9. Body: strength and } \\
\text { endurance. }\end{array}$ & 32 \\
\hline
\end{tabular}

3.3 Family, school and students' willingness to campus football

The core content of the top-level design of the new campus football is the reform of the system and the reconstruction of the mechanism. The main task of top-level design is to solve the "two strengths", that is, the enthusiasm of principals and parents. Principals, parents and students are the three major factors that affect the popularization of campus football and the number of football players. Principals are the makers and executors of school policies, and their psychological willingness to campus football determines the development trend of campus football. Parents are the first guardians of children, and their attitude and willingness to participating in campus football determines the number of students in campus football and the scale of football development. Students are the subjects who directly participate in campus football. Students' psychological willingness to participating in campus football will greatly affect the number of students in campus football. Based on the psychological willingness of family, school and students, which greatly affects the development scale, the popularization and the number of students participating in campus football, this paper made some 
questionnaires to parents, principals and students. And the survey results are shown in Table 4, Table 5 and Table 6 .

Table 4. Questionnaire of the principal's willingness to campus football $(\mathrm{N}=233)$

\begin{tabular}{c|c|c|c|c|c|c|c}
\hline School stage & $\begin{array}{c}\text { The overall } \\
\text { number of } \\
\text { people }\end{array}$ & $\begin{array}{c}\text { Very } \\
\text { willing }\end{array}$ & Percentage\% & Willingness & Percentage\% & Unwillingness & Percentage\% \\
\hline Primary school & 58 & 35 & 60.3 & 15 & 25.9 & 8 & 13.8 \\
\hline $\begin{array}{c}\text { Junior high } \\
\text { school }\end{array}$ & 58 & 4 & 6.9 & 5 & 8.6 & 49 & 84.5 \\
\hline $\begin{array}{c}\text { Senior high } \\
\text { school }\end{array}$ & 58 & 3 & 5.2 & 4 & 6.9 & 51 & 87.9 \\
\hline University & 59 & 45 & 77.6 & 11 & 19 & 2 & 3.4 \\
\hline
\end{tabular}

Table 5. Questionnaire of the parents' willingness to campus football $(\mathrm{N}=500)$

\begin{tabular}{c|c|c|c|c|c|c|c}
\hline School stage & $\begin{array}{c}\text { The overall } \\
\text { number of } \\
\text { people }\end{array}$ & $\begin{array}{c}\text { Very } \\
\text { willing }\end{array}$ & Percentage\% & Willingness & Percentage\% & Unwillingness & Percentage\% \\
\hline $\begin{array}{c}\text { Primary } \\
\text { school }\end{array}$ & 125 & 83 & 66.4 & 32 & 25.6 & 10 & 8 \\
\hline $\begin{array}{c}\text { Junior high } \\
\text { school }\end{array}$ & 125 & 15 & 12 & 26 & 20.8 & 84 & 67.2 \\
\hline $\begin{array}{c}\text { Senior high } \\
\text { school }\end{array}$ & 125 & 12 & 9.6 & 23 & 18.4 & 90 & 72 \\
\hline University & 125 & 95 & 76 & 22 & 17.6 & 8 & 6.4 \\
\hline
\end{tabular}

Table 6. Questionnaire of the students' willingness to campus football $(\mathrm{N}=501)$

\begin{tabular}{c|c|c|c|c|c|c|c}
\hline $\begin{array}{c}\text { School } \\
\text { Stage }\end{array}$ & $\begin{array}{c}\text { The Overall } \\
\text { Number of } \\
\text { People }\end{array}$ & $\begin{array}{c}\text { Very } \\
\text { Willing }\end{array}$ & Percentage\% & Willingness & Percentage\% & Unwillingness & Percentage $\%$ \\
\hline $\begin{array}{c}\text { Primary } \\
\text { school }\end{array}$ & 125 & 88 & 70.4 & 28 & 22.4 & 9 & 7.2 \\
\hline $\begin{array}{c}\text { Junior } \\
\text { high } \\
\text { school }\end{array}$ & 125 & 90 & 72 & 31 & 24.8 & 4 & 3.2 \\
\hline $\begin{array}{c}\text { Senior } \\
\text { high } \\
\text { school }\end{array}$ & 125 & 87 & 69.6 & 26 & 20.8 & 12 & 9.6 \\
\hline University & 126 & 92 & 73 & 29 & 23 & 5 & 4 \\
\hline
\end{tabular}

Table 4 of the survey results shows that the percentage of principals' support for students participating in campus

football activities in primary school is $86.2 \%$, and the percentage of disapproval is $23.8 \%$. The percentage of university principals' support for students participating in campus football activities is $96.6 \%$, and the percentage of disapproval is $3.4 \%$. The percentage of principals' support for students participating in campus football activities in junior high school is $15.5 \%$, and the percentage of disapproval is $84.5 \%$. The percentage of senior high school principals' support for students participating in campus football activities is $12.1 \%$, and the percentage of disapproval is $87.9 \%$.

Table 5 of the survey results shows that the percentage of parents' support for children participating in campus football activities in primary school is $92 \%$, and the percentage of disapproval is $8 \%$. The percentage of parents in university who support their children's participation in campus football activities is $93.6 \%$, while the percentage of disapproval is $6.4 \%$. The percentage of parents' support for children's participation in campus football activities in junior middle school is $32.8 \%$, and the percentage of disapproval is $67.2 \%$. In high school, the percentage of parents' support for children participating in campus football activities is $28 \%$, and the percentage of disapproval is $72 \%$.

The reason for this result is that primary school students have less academic pressure and more time to participate in 
various sports activities. And university curriculum is relatively loose, so university students have enough time for sports activities. While in junior and senior high schools, students face the pressure of entering the higher school and have heavy homework. Besides, principals are facing the pressure of rate of admission into the higher school, and parents have high demands on their children's entering the higher school. All these make students have no time for extracurricular physical exercises.

Table 6 of the survey results shows that the support rate of primary school students participating in campus football activities is $92.8 \%$, junior high school students participating in campus football activities is $96.8 \%$, senior high school students participating in campus football activities is $90.4 \%$, and college students participating in campus football activities is $96 \%$. It shows that students in four levels of schools all like football. One of the reasons for this phenomenon is to reduce stress. Students are under too much pressure to study, especially junior high school and senior high school students who are facing the pressure of further studies. In addition to studying in class, there are a lot of homework outside class, so they basically have no time for extracurricular activities. Secondly, the characteristics of football attract them. Football is a combative sport that needs fierce confrontation. Its skills and tactics are very complicated and it is difficult to master the movements. Moreover, the football match takes a long time, requires a large field and consumes a lot of physical energy. And the rules of football match are concise and the equipment is simple. Therefore, the support rate of students for campus football is high.

\subsection{The competition system of campus football}

Carrying out campus football competition is one of the most important ways to promote the teaching and daily activities of campus football. And it is also an important symbol to test the development level, culture and training level of campus football. By constructing a four-level league system of city, district, school, and class, and perfecting the four-level league system from elementary school, junior high school, high school to university, a new pattern of campus football competition activities with "competition within school, league between schools and selection at municipal level" has been formed. The spatial characteristics of campus football determine the type of its pluralistic competition system, which needs to be carried out on the basis of promoting teaching and testing teaching with schools as the core. Understanding and analyzing the present situation of campus football competition system in Zhejiang Province is helpful to promote the development of campus football in Zhejiang Province. The classification and grouping of campus football matches in Zhejiang Province are shown in Figure 1 and Figure 2.

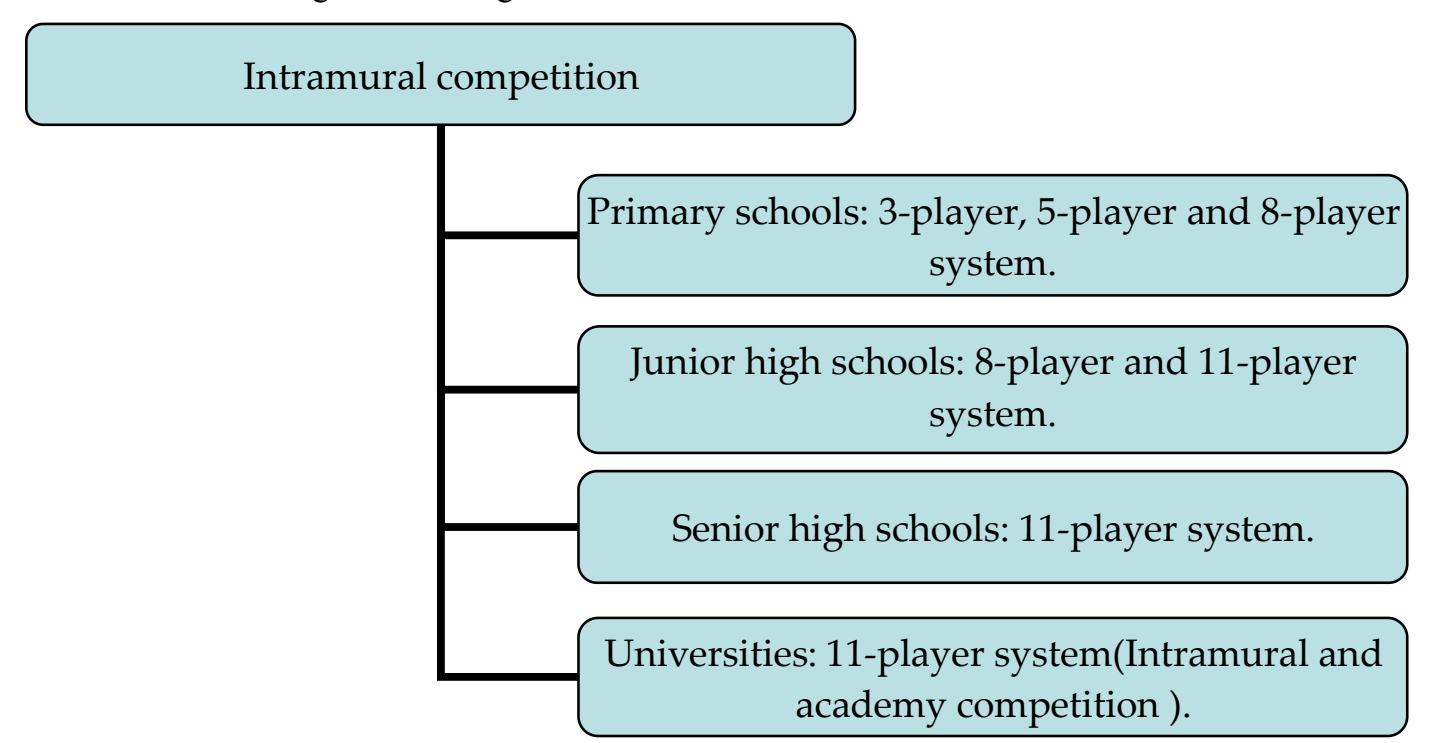

Figure 1. The classification of campus football competition in Zhejiang Province 


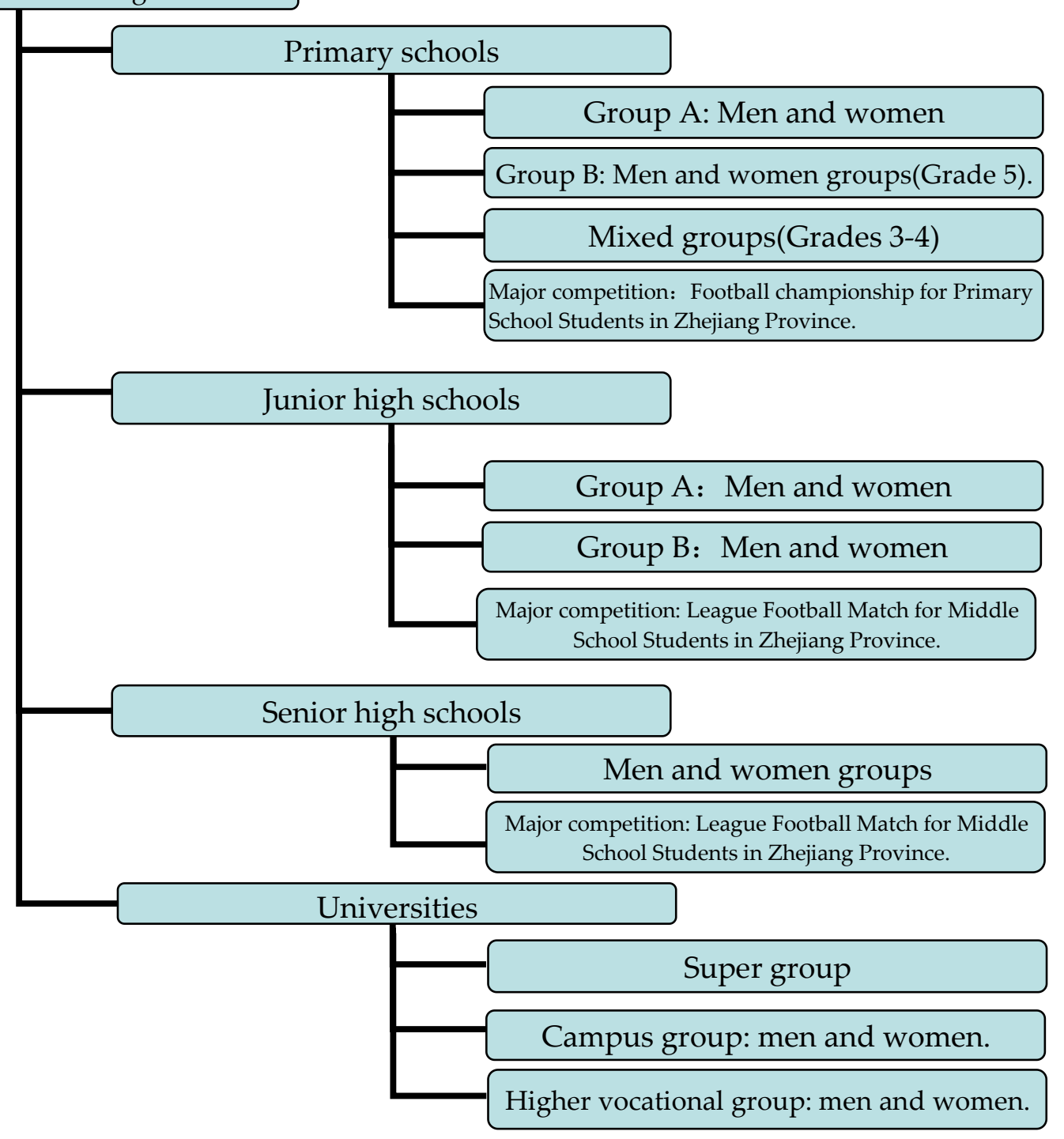

Figure 2. The group of campus football competition

As shown in Figure 1, the competitions in schools in Zhejiang Province are mainly classified into 11-player system, 8player system, 5-player system and 3-player system. Primary school students in lower grades take playing games as their main form of participation, because they are young and have no concept of competition. With the increase of grade and age, the small group competition gradually transits to the whole team competition. The four-level campus football match is mainly composed of 11 players.

As shown in Figure 2, there are a group A, a group B and a mixed group in the inter-school football match. In primary school, there are no fixed competitions in grades 1-2, grades 3-4 are mixed into groups, and grades 5-6 are divided into male and female groups. In junior high school, it is divided into men's team and women's team in group A, and men's team and women's team in group B. In senior high school, it is divided into two groups: male and female. At the university stage, it is divided into super group, male group and female group on campus, and male group and female group in higher vocational colleges.

Coaches are the instructors of campus football competition and training. This paper makes a questionnaire survey on the source, age, educational background and professional title of campus football coaches. See table 7 for details. As shown in Table 7, most of the campus football teachers or coaches in 11 cities in Zhejiang Province have not experienced 
specialized football training, and the proportion of non-football-major physical education teachers is very large. Most of the campus football teachers and coaches are middle-aged and young teachers aged 24-45. The academic qualifications structure shows a trend of cold at both ends and hot in the middle. The proportion of people with college and doctoral degrees is small, while the proportion of people with bachelor degree is the highest, and the proportion of people with master degree is second. The structure of professional titles and academic qualifications is similar, with teaching assistants and professors accounting for a small proportion, lecturers accounting for the largest proportion, and associate professors accounting for the second.

Table 7. Questionnaire of learning sources of campus football coaches in 11 cities of Zhejiang Province $(\mathrm{N}=867)$

\begin{tabular}{c|c|c|c}
\hline $\begin{array}{c}\text { First-class index of } \\
\text { learning source }\end{array}$ & $\begin{array}{c}\text { Secondary index of learning } \\
\text { sources }\end{array}$ & Total number of people & Percentage $\%$ \\
\hline \multirow{4}{*}{ Source } & Retired athletes & 123 & 14.2 \\
\cline { 2 - 4 } & Football major & 232 & 26.8 \\
\cline { 2 - 4 } & Non-football major & 486 & 56 \\
\cline { 2 - 4 } & Others & 26 & 3 \\
\cline { 2 - 4 } & $24-35$ & 311 & 35.9 \\
\cline { 2 - 4 } & $36-45$ & 342 & 24.7 \\
\hline \multirow{3}{*}{ Academic Degree } & Associate Bachelor & 214 & 0.6 \\
\cline { 2 - 4 } & Bachelor & 5 & 59.4 \\
\cline { 2 - 4 } & Master & 326 & 37.6 \\
\cline { 2 - 4 } & Doctor & 21 & 2.4 \\
\hline \multirow{2}{*}{ Professional Title } & Teaching Assistant & 92 & 70.6 \\
\cline { 2 - 4 } & Lecturer & 660 & 11.8 \\
\cline { 2 - 4 } & Associate Professor & 102 & 1.5 \\
\cline { 2 - 4 } & Professor & 13 & \\
\hline
\end{tabular}

\section{Conclusions and Suggestions}

\subsection{Conclusions}

The penetration rate of campus football in Zhejiang Province is polarized. That is, the high penetration rate in economically developed areas and the low penetration rate in economically underdeveloped areas. The contents of football courses in primary, secondary and tertiary schools follow the laws of sports, the formation and development of sports skills and the physical and mental development of students. There is no uniform standard for the evaluation methods of campus football in three levels of schools. Headmasters and parents have a reverse trend in their psychological needs for students to participate in football activities, while students have a positive trend in their psychological needs for participating in campus football activities. In Zhejiang Province, campus football matches are classified as follows: 3-player, 5-player, 8player and 11-player, among which 11-player matches are the main form. The competition groups in primary and secondary schools are men's and women's teams in Group A, men's and women's teams in Group B. Universities have super groups, campus groups and higher vocational groups. Campus football coaches are mostly non-football professional teachers, with young and middle-aged as the main force, and their academic qualifications and professional titles are mainly undergraduate degrees and lecturers.

\subsection{Suggestions}

In view of the polarization of campus football penetration rate in Zhejiang Province, we can carry out peer-to-peer assistance policy, that is, schools with better campus football development will help schools in underdeveloped areas to develop campus football in a one-to-one way. It can absorb social funds to make up for the shortcomings of insufficient funds for the development of campus football, and improve the treatment of teachers in underdeveloped areas to attract more professional football teachers to teach. Led by the Education Department of Zhejiang Province and the Sports Bureau 
of Zhejiang Province, sports associations at all levels organized experts to demonstrate the football school-based curriculum, and football backbone teachers compiled the football school-based curriculum. The education administrative departments and sports administrative departments in various places combine with each other to introduce policies to promote the healthy development of campus football, encourage schools to carry out campus football activities, and encourage parents to support their children to participate in campus football activities. In order to improve the quality of campus football teaching and make up for the shortage of football professional teachers, on the one hand, we should introduce football professional teachers vigorously, on the other hand, we should send existing teachers out to participate in football training.

\section{Conflicts of Interest}

The author declares no conflicts of interest regarding the publication of this paper.

\section{About the author}

1. Chongjiang Zhan, male, born in 1976 in Shangrao, Jiangxi Province, associate professor, postgraduate degree. main research direction is physical education and sports training.

2. Boliang Xu, male, born in 1980 in Zhuji, Zhejiang Province, with intermediate professional title, bachelor degree, main research direction is physical education and sports training.

3. Li Cao, male, born in 1982 in Shaoxing, Zhejiang Province, lecturer, postgraduate degree, main research direction is physical education.

\section{References}

[1] Li J.X. (2012). Research on the Development Strategy of National Youth Campus Football Activities. Shanghai Institute of Physical Education, Shanghai.

[2] Gong B., Tao R.C. and Dong Z.M. (2017). Discussion on Some Major Issues of Campus Football in China at Present. Journal of Shanghai University of Sport, 41(1): 61.

[3] Wang D.F. (2018). From "Having" to "Being Strong": the Strategic Orientation and Development Direction of Youth Campus Football in the New Era. Sports Science, 38(4): 4-5.

[4] Ministry of Education of the People's Republic of China. (2019). National Youth Campus Football Five-Year Report Card Released. 27,000 Primary and Secondary Schools can Have a Football Lesson Every Week. China Education Daily. http://www.moe.gov.cn/fbh/live/2019/51635/mtbd/201912/t20191223_413116.html

[5] Zhang X.X. (2015). School-based Curriculum Development of Campus Football Activities in Primary and Secondary Schools. Journal of Physical Education, 22(3): 90.

[6] Huan W. and Qin Y. (2016). Development of Evaluation Criteria for Students' Sports Skills in Middle School of Campus Football. Journal of Shandong Institute of Physical Education, 32(3): 103.

[7] Mao Z.M., Liu T.B. and Zang L.H. (2015). On the Top-level Design of "New Campus Football". Journal of Wuhan Institute of Physical Education, 49(3): 61.

[8] Textbook Committee of National Institute of Physical Education. (1992). Football. People's Sports Publishing House, Beijing.

[9] Luo B.Q. and Pang B. (2019). Research on the Current Situation of Campus Football Competition System in Beijing. Journal of Capital Institute of Physical Education, 31(2): 157-158.

[10] Liang P.G. (2016). Diversified Campus Football Competition System Construction. Sports Culture Guide, (4): 143. 